\title{
The significance and lag-time of deep through flow: an example from a small, ephemeral catchment with contrasting soil types in the Adelaide Hills, South Australia
}

\author{
E. Bestland ${ }^{1}$, S. Milgate ${ }^{1}$, D. Chittleborough ${ }^{2}$, J. VanLeeuwen ${ }^{3}$, M. Pichler ${ }^{1}$, and L. Soloninka ${ }^{1}$ \\ ${ }^{1}$ Earth Sciences, SoCPES, Flinders University, 5001, South Australia \\ ${ }^{2}$ School of Earth and Environmental Science, University of Adelaide, South Australia \\ ${ }^{3}$ School of Natural and Built Environments, University of South Australia, South Australia
}

Received: 30 January 2009 - Published in Hydrol. Earth Syst. Sci. Discuss.: 24 March 2009

Revised: 7 July 2009 - Accepted: 8 July 2009 - Published: 16 July 2009

\begin{abstract}
The importance of deep soil-regolith through flow in a small $\left(3.4 \mathrm{~km}^{2}\right)$ ephemeral catchment in the Adelaide Hills of South Australia was investigated by detailed hydrochemical analysis of soil water and stream flow during autumn and early winter rains. In this Mediterranean climate with strong summer moisture deficits, several significant rainfalls are required to generate soil through flow and stream flow [in ephemeral streams]. During autumn 2007, a large $(127 \mathrm{~mm})$ drought-breaking rain occurred in April followed by significant May rains; most of this April and May precipitation occurred prior to the initiation of stream flow in late May. These early events, especially the $127 \mathrm{~mm}$ April event, had low stable water isotope values compared with later rains during June and July and average winter precipitation. Thus, this large early autumn rain event with low isotopic values $\left(\delta^{18} \mathrm{O}, \delta \mathrm{D}\right)$ provided an excellent natural tracer. During later June and July rainfall events, daily stream and soil water samples were collected and analysed. Results from major and trace elements, water isotopes $\left(\delta^{18} \mathrm{O}, \delta \mathrm{D}\right)$, and dissolved organic carbon analysis clearly demonstrate that a large component of this early April and May rain was stored and later pushed out of deep soil and regolith zones. This pre-event water was identified in the stream as well as identified in deep soil horizons due to its different isotopic signature which contrasted sharply with the June-July event water. Based on this data, the soil-regolith hydrologic system for this catchment has been re-thought. The catchment area consists of about $60 \%$ sandy and $40 \%$ clayey soils. Regolith
\end{abstract}

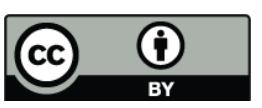

Correspondence to: E. Bestland (erick.bestland@flinders.edu.au) flow in the sandy soil system and not the clayey soil system is now thought to dominate the deep subsurface flow in this catchment. The clayey texture contrast soils had rapid response to rain events and saturation excess overland flow. The sandy soils had delayed soil through flow and infiltration excess overland flow. A pulse of macropore through flow was observed in the sandy soils three days after the rainfall event largely ended. The macropore water was a mixture of preevent and event water, demonstrating the lag-time and mixing of the water masses in the sandy soil system. By contrast, the clayey soil horizons were not dominated by pre-event water, demonstrating the quicker response and shallow through flow of the clayey soil system. Thus, the sandy terrain has a greater vadose zone storage and greater lag time of through flow than the clayey terrain.

\section{Introduction}

Flow pathways through soil and regolith and their relation to stream flow and surface water chemistry have been a focus in several different types of studies. Atmospheric acid deposition and its affect on streams and lakes was an early area of investigation that combined soil hydrochemistry, atmospheric deposition rates and chemistry with surface water chemistry (Likens et al., 1977, 1996; Probst et al., 1990). Silicate weathering rates and the fluxes of weathered product including its link to carbon cycle models provided further progress in the understanding of these complex catchment systems (Aberg et al., 1989; Edmond et al., 1995; Kump et al., 2000; Shand et al., 2007). Added to the above geochemical focused studies are hydrologic investigations in which

Published by Copernicus Publications on behalf of the European Geosciences Union. 


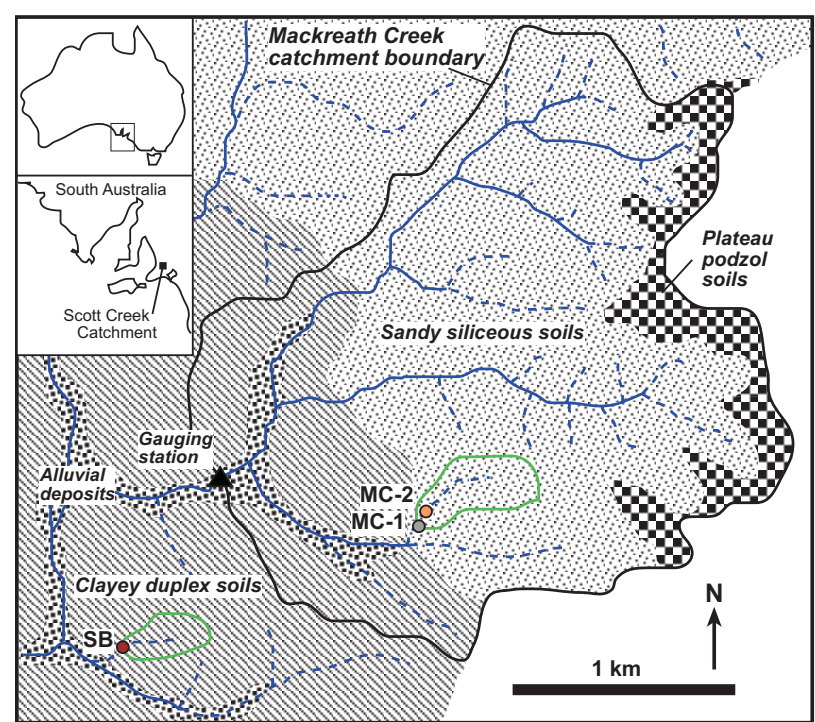

Fig. 1. Location map of the Mackreath Creek catchment showing surface drainages, the distribution of sandy and clayey soils, soil water collection sites (MC1, MC2, SB), and gauging station.

components of stream flow are identified through utilization of techniques and methods of soil and water hydrogeochemistry (Sklash and Farvolden, 1979, 1982; Kennedy et al., 1986; Land et al., 2000). These studies have highlighted a number of complications that arise in the study of even the most simple catchments: soil and bedrock heterogeneity, groundwater or baseflow input, seasonal changes to the system in terms of hydrogeochemical (and biogeochemical) inputs, and anthropogenic disturbances such as airborne pollutants and agricultural amendments. It is clear that progress toward a comprehensive understanding of the diverse range of catchments requires detailed hydrogeochemical studies of soil, regolith, groundwater, and surface water. The study presented here is based on extensive analysis of soil water, overland flow, stream water, and precipitation during a moderate sized precipitation event in a small ephemeral catchment in a strongly Mediterranean climate. In this study a catchment was selected that had minimal saturated groundwater inputs which allowed the focus to be on the unsaturated and perched soil and regolith systems.

One complicating parameter in the catchment studies cited above is the presence of permanent groundwater and its contribution to stream flow. Thus in such catchments, groundwater input into stream and soil water needs to be separated from unsaturated and perched flow pathways through soil and regolith. Evaluating the groundwater component has led to assumptions about the homogeneity of groundwater as well as assumptions concerning vadose soil water being a negligible source to stream flow (Sklash and Farvolden, 1982). Later studies by McDonnell et al. (1991), McGlynn et al. (2002) and others established the importance of vadose zone water in stream flow generation, although in the very humid Maimai catchment of New Zealand that they studied, groundwater dominated over soil water.

In the study presented here, a gauged ephemeral stream (Mackreath Creek) of $3.4 \mathrm{~km}^{2}$ catchment area in the Adelaide Hills of South Australia was investigated with the aim of characterising through flow pathways and identifying their contribution in the resulting stream flow (Fig. 1). In humid climate settings, differentiating flow paths may be important in terms of flood response, soil erosion, contaminant transport, and hydropedology (Lin, 2003). These concerns are also valid in the strongly Mediterranean climate of the Adelaide region. Important in the sub-humid to semi-arid climatic setting of much of Australia, with its highly variable rainfall, is the understanding of soil-regolith flow paths. The amount of precipitation necessary to generate deep, sustained soil-regolith through flow is critical to predicting landscape response to climate change. Groundwater recharge estimates also rely on assumptions regarding duration and extent of soil-regolith saturation.

Our original hypothesis regarding the sources and timing of stream flow generation during a precipitation event was based on assumptions of slow Darcian flow in the clayey soil-regolith system compared to more rapid subsurface flow in the sandy soil-regolith system. In this original conceptual model, macropores were thought to be important in both sandy and clayey systems; however at the hill slope scale macropores would largely be hydraulically disconnected. Thus the overall grainsize distribution of the soil-regolith and its resultant hydraulic properties would determine the rapidity of the hydraulic response to precipitation.

\section{Background}

Mechanisms of stream flow generation in ephemeral streams are dominated by through flow, overland flow, and perched zones of saturated soil and regolith water. Through flow or lateral subsurface flow has been shown to be an important flow pathway in hilly Mediterranean climate catchments (Kennedy et al., 1986). In humid settings with thick soils through flow has been shown to be the predominant mechanism of stream flow generation (Pearce et al., 1986; Sklash et al., 1976). In the Adelaide Hills or Mount Lofty Ranges (MLR) of South Australia, Cox et al. (2002) identified through flow to be the most important transport pathway for contaminants during years of average or below average rainfall. Mixing between through flow and overland flow on hill slopes in the MLR has been observed by Chittleborough et al. (1992) to produce similar hydrochemical signatures between flow paths.

In settings such as the MLR, soil through flow is produced by a combination of matrix flow and macropore flow (Smettem et al., 1991; Leaney et al., 1993; Stevens et al., 1999; Cox et al., 2002). Water flowing through the soil 
matrix generally obtains a signature similar, although dilute, to that of the exchange pool of the soil (Cox et al., 2002), while macropores primarily act as a physical conduit for water to flow through and consequently the exchange pool has a lesser effect on the chemistry of water (Newman et al., 1998). Down-slope mixing of matrix flow and macropore flow can homogenise the hydrochemistry of these two pathways (Chittleborough et al., 1992).

An important aspect of tracing flow paths in catchment systems is the evaluation of pre-event water (Pinder and Jones, 1969; Genereux and Hooper, 1998; Buttle, 1998; Brown et al., 1999; Shanley et al., 2002). Such evaluation commonly entails an analysis of the groundwater input into the stream. In an ephemeral system such as Mackreath Creek where the surface water is disconnected from the water table (Fig. 2), an evaluation of pre-event water held in the vadose zone can be made by an analysis of the precipitation, in this case autumn and winter rainfall leading up to the analysed event.

\section{Study catchment}

The Scott Creek area, which includes the Mackreath Creek study site, experiences a Mediterranean climate with cool moist winters and warm dry summers. Average daily temperatures range from $14-27^{\circ} \mathrm{C}$ in summer to $8-14^{\circ} \mathrm{C}$ in winter. The MLR receives strong seasonal rainfall, with $85 \%$ of rainfall in winter between May and September (BOM, 2007). A yearly rainfall average of $804 \mathrm{~mm} / \mathrm{yr}$ has been collected at the site (Scott Bottom rainfall collector) at an elevation of $210 \mathrm{~m}$, which has been in operation since 1991 (James-Smith and Harrington, 2002). Evaporation of $1555 \mathrm{~mm} / \mathrm{yr}$ is measured at the nearest Class A evaporation pan at Mt. Bold; evaporation exceeds rainfall from October to May (spring, summer and autumn).

Mackreath Creek is ephemeral with winter flows of a few weeks duration during drought years and 4-6 months duration in average and above average precipitation years. Flows range from $1.21 / \mathrm{s}-5.81 / \mathrm{s}$ for winter non-storm flows, 12 $1161 / \mathrm{s}$ for typical winter storm flows, and 232-347 1/s for two year peak flows.

South Australia was in a drought during 2006, with nearly $50 \%$ less rainfall than average (BOM, 2007). In 2006, stream flows at Mackreath Creek gauging station lasted only 2 days! In 2006 there was one significant storm event of $40 \mathrm{~mm}$ (over 4 days) which produced the only flow in Mackreath Creek, compared to six events of greater than $40 \mathrm{~mm}$ in 2005 which caused the creek to flow for four months.

The Mackreath Creek study site is a sub-catchment of Scott Creek Catchment and is typical of MLR catchments having $100-300 \mathrm{~m}$ of relief, moderately steep slopes in many areas and narrow riparian-floodplain zones. The study area, as is most of the MLR, is underlain by metamorphosed late Precambrian sedimentary rocks consisting of

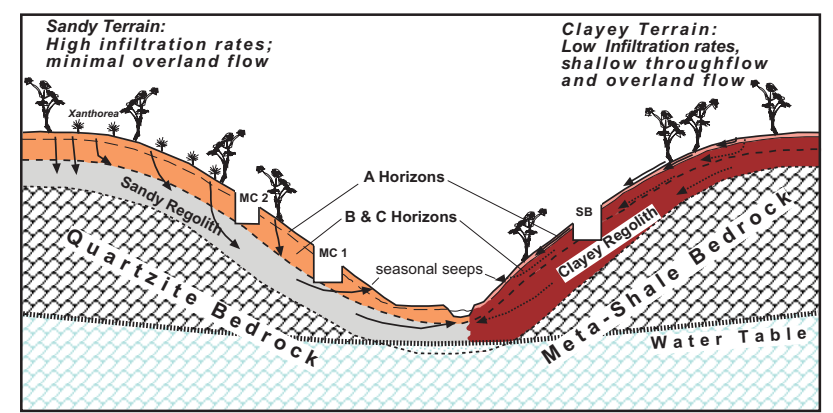

Fig. 2. Schematic cross-section of the Mackreath Creek catchment. The catchment consists of sandy soils over quartzite bedrock and clayey duplex soils over meta-shale bedrock. The sandy soils have high infiltration rates where as the clayey soil system, except for the A horizon, has low infiltration rates.

meta shales, sandstone-quartzite, and minor carbonate units (Priess, 1987). The hydrogeology of the area is that of a fractured rock aquifer (FRA) with large variations in both hydraulic conductivity and groundwater salinity (Barnett et al., 2002; Harrington, 2004a, b). The disconnection between Mackreath Creek surface water and the FRA is demonstrated by the hydraulic head of the FRA at the Mackreath Creek gauging station being lower than the stream bed by 2 to $3 \mathrm{~m}$. At this gauging station there are three piezometers with depths of $16 \mathrm{~m}, 11 \mathrm{~m}$ and $5 \mathrm{~m}$. The logs of these bores have established the fractured rock-regolith boundary at $11 \mathrm{~m}$ depth (Fig. 2).

The Mackreath Creek area has four landscape-soil types: 1) a narrow and shallow alluvial bottom land with sandy silty and clayey soils and deposits, 2) moderate gradient slopes underlain by meta-shale with clayey soils that have strong texture contrast between A and B horizons of the Red Brown Earth to Red Podzolic soil types (Taylor et al., 1974), 3) quartzite dominated moderate to steep slopes with Yellow Podzolic and skeletal stony and sandy soils, and 4) broad ridge tops with eroded relict and podzolized lateritic soils (Fig. 1). Of these four landscape areas, the clayey texture contrast soils and yellow podzolic soils comprise the vast majority of the catchment. Soil thickness is typically between $1-2 \mathrm{~m}$. Weathered bedrock or regolith of several meters in thickness typically occurs beneath the soil horizons (Fig. 2). A number of 3-4 m deep backhoe trenches have been dug in the area and combined with drill logs has established regolith thickness and type. Where the regolith occurs over meta shale, it consists of a stony massive, heavy clay. And where the regolith occurs over quartzite, it consists of silty stony sand with some clayey zones. Small quartzite outcrops occur scattered along steep side slopes and narrow ridge tops.

Soil water collectors were installed in the two main soil types; clayey texture contrast soils and yellow podzolic soils (Fig. 1). Mackreath Creek soil water collection sites MC1 


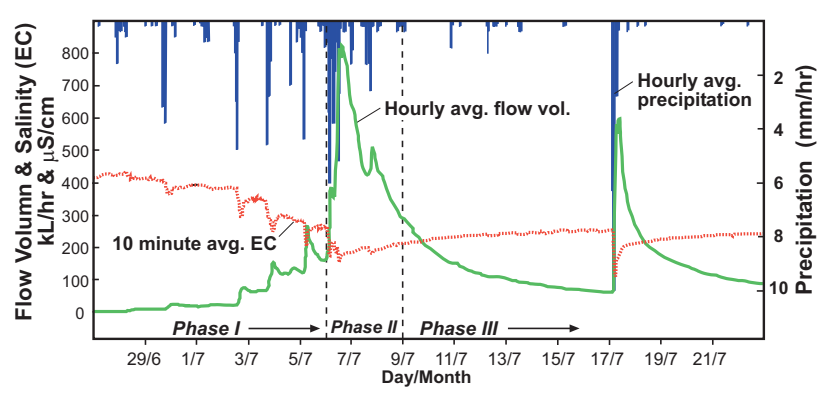

Fig. 3. Hydrograph of stream flow and rainfall of the late Juneearly July 2007 precipitation event. Electrical conductivity from automatic logger is also shown. Phase I refers to the rising limb of the hydrograph with a duration of about 7 days. Phase II refers to peak precipitation and stream flow with duration of 3 days. Phase III refers to the falling limb and has a duration of 8 days until the precipitation event of 17 June.

and $\mathrm{MC} 2$ are positioned to collect water flowing through sandy soil horizons (Fig. 2). Scott Bottom site (SB) represents flow through a texturally contrasting clayey soil. This site is just outside Mackreath Creek sub-catchment and is assumed to have soil water and overland flow hydrochemical signatures that are much the same as water flowing through the texture contrast soils at Mackreath Creek. The Scott Bottom (SB) site is underlain by the same meta shale geologic formation. Clayey texture contrast soils in Mackreath creek occur on slopes lacking either 0-order catchments or large areas of homogenous meta-shale and clayey texture contrast soil substrate.

Mackreath Creek catchment is predominately comprised of native vegetation; however, substantial human impacts have occurred and consist of land clearance on lower gradient slopes with clayey texture contrast soils, a few farm dams, and bulldozed fire tracks on most ridge tops. Native vegetation in this area consists of eucalyptus trees with lesser acacia trees. Most clayey soil sites have been cleared to some extent, and are now being replanted with native trees and shrubs. These areas are presently a mix of thick grass and large eucalyptus trees (up to $30 \mathrm{~m}$ ) comprising a savannah landscape. Most sandy soil sites have not been cleared and consist of shorter trees (5-10 m) and an understory of shrubs, heath and scattered grasses comprising an open woodland to woodland. Deep sandy soils have areas of bracken fern. Rocky sandy soils have xanthorrhoea (grass trees) and casuarinaceae (sheoaks) in addition to eucalypts.

\section{Methods}

The three soil water collector sites, MC1, MC2, and SB were instrumented with one overland flow collector and two interflow collectors. Overland flow collectors consisted of $20 \mathrm{~m}$ by $20 \mathrm{~cm}$ metal sheeting arranged into a V-shape to funnel water downhill. The metal sheets were inserted $5 \mathrm{~cm}$ into the ground surface and were held in place by stakes every $2 \mathrm{~m}$. Polyethylene tubing was attached to the lowest point to channel water down slope and into a $25 \mathrm{~L}$ sample container.

To collect soil through flow, three meter deep trenches were dug at each site by a backhoe (long axis of trench was downhill) and access to the trenches was gained from the downhill side. Channels were dug to drain water from each trench. Trenches were covered with plastic tarpaulins to prevent direct contact of rainfall with the side walls of the trench, which could cause erosion and contaminate through flow samples. A low levee of dirt surrounded the upper parts of the trench so that overland flow would be diverted. The face of each trench (uphill side) was instrumented with two fibreglass wick through flow collectors with $0.16 \mathrm{~m}^{2}$ area of soil contact at the $\mathrm{A} / \mathrm{B}$ and $\mathrm{B} / \mathrm{C}$ horizons.

Soil through flow collectors consist of a $1 \mathrm{~m}$ length of fibreglass wick with $10 \mathrm{~cm}$ of frayed wick at one end. This was used to spread across a base plate which acted as a contact with soil water. The rest of the wick ran through PVC tubing to an outlet where a $25 \mathrm{~L}$ container was connected to collect soil water. Garden weed mat was used to cover the base plate to pre-filter soil water and prevent soil entering the collector. Chiselling and digging tools were used to undercut a 50 by $50 \mathrm{~cm}$ cavern in the face of the trench so collectors could be installed. The roof of the undercut was made as flat as possible and soil from the roof of the undercut was mixed with water to create a slurry of soil which was put on top of each collector. Each collector was propped in position using two car jacks and pieces of wood to equalise the force (one on each side of the base plate).

At $\mathrm{A}$ and $\mathrm{B}$ horizons at $\mathrm{MC} 2$ and $\mathrm{A}$ horizons at both $\mathrm{MC} 1$ and $\mathrm{SB}$, through flow collectors were connected to containers directly by $45 \mathrm{~mm}$ holes drilled through the lid of the $25 \mathrm{~L}$ containers. High water levels in the trenches at SB and MC1 required tubing to be connected to the PVC piping of the through flow collector and ran out of the trench downhill to a container.

An auto-logger installed in the stream provided a continuous record of electrical conductivity (EC) variations. The logged data from the stream was corrected with a hand-held and calibrated EC meter; corrected data is plotted in Figs. 3 and 4. In addition, total dissolved solids (TDS) were calculated from major and trace element analysis by ICP MS (Inductively Coupled Plasma Mass Spectrometry). A very good correlation of $R^{2} 0.970$ was observed between corresponding hand held EC measurements (converted to TDS using $0.66 \mathrm{EC}$ ) and total dissolved solids from ICP MS analyses.

Prior to filtering, samples were tested for alkalinity using a HACH titration alkalinity kit to determine the concentration of carbonates in the system. Filtering was undertaken in the laboratory a few hours after sampling using pressure packs to force sample through a pre-filter and a $0.45 \mu \mathrm{m}$ filter. $60 \mathrm{ml}$ of sample was stored in a bottle for 72 element suite analysis and acidified to a $\mathrm{pH}$ less than 2 using nitric 
acid $\left(\mathrm{HNO}_{3}\right)$. Water samples were transferred the same day as sampling and stored in a $30 \mathrm{ml} \mathrm{McCartney} \mathrm{bottle} \mathrm{for} \mathrm{water}$ isotope $\left({ }^{2} \mathrm{H} /{ }^{1} \mathrm{H}\right.$ and $\left.{ }^{18} \mathrm{O} /{ }^{16} \mathrm{O}\right)$ analysis. Samples were kept cool during transport to prevent evaporation. To prevent exchange of water vapour with the air, McCartney bottles were completely filled, electrical tape was used to seal the lid of the bottle and samples were stored upside-down until analysis.

In total 75 samples were selected for 72 element suite analysis at Acme Analytical Laboratories, Canada, using ICP MS. Stable isotopes of oxygen and hydrogen were analysed at UC Davis Stable Isotope Facility, California using a Los Gatos Research Liquid Water Isotope Analyser. Standards were run every five samples to ensure correct calibration of equipment, which enabled an accuracy of $0.2 \%$ and $0.6 \%$ for ${ }^{18} \mathrm{O} /{ }^{16} \mathrm{O}$ and ${ }^{2} \mathrm{H} /{ }^{1} \mathrm{H}$ respectively.

\section{Results}

\subsection{Electrical conductivity/salinity}

Electrical conductivity measurements were made of Mackreath Creek at the gauging station, soil horizon through flow, and overland flow before, during and after the precipitation event of late June and early July (2007) (Figs. 3 and 4). This precipitation-stream flow event began approximately on 30 June (2007) with daily showers. These showers increased in frequency over the next 7 days culminating in a rainfall event on 6 July. This build-up of rainfall and rise in stream flow is termed phase I in this study (Fig. 3). The three day peak of stream flow following the rainfall of the 6 is termed phase II. And the falling limb of the hydrograph with a few late showers is phase III; this lasted for 8 days until the next significant precipitation event.

Due to low sample volume in the sandy soils during the lead-up to the precipitation event, and in fact during the first half of the event, EC measurements were not made of these samples; however, major and trace elemental analysis and oxygen and hydrogen isotope analyses were obtained from these low volume samples.

Clayey soil EC measurements show predictable decreases in salinity from B horizon to A horizon and to overland flow (Fig. 4). Overall, the A horizon salinity was $10 \%$ lower than the B horizon values. During the beginning of the event, overland flow was $70 \%$ lower than B horizon values. However, dilution of soil horizon EC during peak precipitation decreased the difference to about $15 \%$. During the waning stage of the event, overland flow EC reached parity with A horizon values.

An important point to make in regard to the clayey soil water EC values is that most of the stream EC measurements (except during peak flow dilution) are higher in EC (salinity) than temporally corresponding B horizon values. Thus in this small catchment, B horizon water of clayey soils from grav-

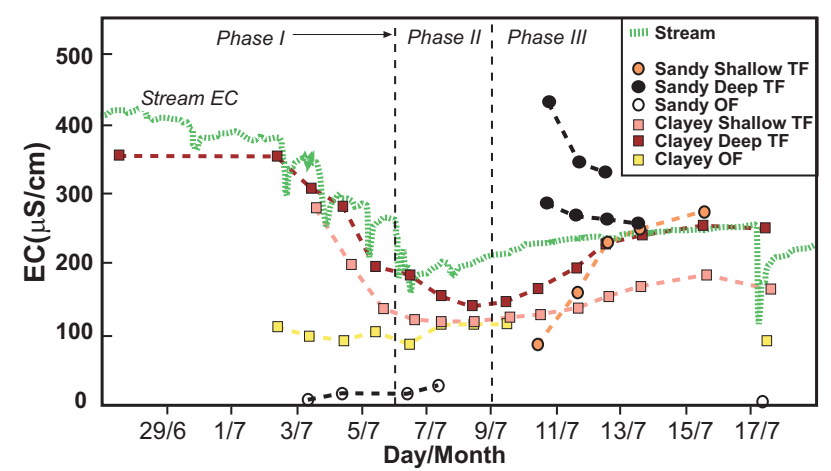

Fig. 4. Electrical conductivity of Mackreath Creek (corrected from automatic logger), deep and shallow through flow (TF) from the sandy soil system, deep and shallow through flow from the clayey soil system, and overland flow (OF) from both the clayey and sandy soil systems.

ity collectors and from the mid-slope position sampled, do not have higher EC (salinity) than the majority of the stream flow.

As stated previously, EC measurements for the sandy soil sites were incomplete due to small sample size during phase I and II of the event. Nonetheless, relatively high EC values and decreasing trends were measured for sandy deep through flow during phase III of the event (Fig. 4). Sandy shallow through flow had increasing EC during phase III reaching parity with the deep through flow, probably due to mixing of water masses during the event. Overland flow EC values were very low, the lowest of all the measurements, indicating the low exchange phase reservoir in the A horizon of these sandy soils. Low EC of sandy overland flow is also due to a lack of saturation excess overland flow in these high infiltration sandy soils.

During phase III of the event, through flow water filled the two trenches at the sandy soil site. Through flow water did not fill the clayey trench. This rise in perched soil-regolith water lasted for three days and was a mix of observed macropore flow and matrix flow from the B horizon. Sandy soil macropore flow was sampled directly in the up-slope trench site (MC2) as actual macropore flow and included in the deep sandy through flow. The EC values from the perched soilregolith water were higher than stream EC values, despite the mixing of macropore flow. EC values show dilution trends later during phase III. The perched soil-regolith water was higher in EC than the B horizon macropore flow.

\subsection{Elemental concentrations}

Similar to overall EC values, major ion concentrations (chloride, sodium, bicarbonate, silica, calcium and magnesium) in stream flow and in most soil water show dilution trends during and after peak flow (Fig. 5, bicarbonate, calcium and magnesium not shown). Major elements chloride and sodium 
Table 1. Selected elemental concentrations from ICP analysis.

\begin{tabular}{|c|c|c|c|c|c|c|c|c|c|c|c|c|c|c|}
\hline & & $\mathrm{Al}$ & $\mathrm{Ba}$ & $\mathrm{Br}$ & $\mathrm{Ca}$ & $\mathrm{Cl}$ & $\mathrm{Fe}$ & $\mathrm{K}$ & $\mathrm{Mg}$ & $\mathrm{Na}$ & S & $\mathrm{SO} 4$ & $\mathrm{Si}$ & $\mathrm{Sr}$ \\
\hline Date/Time & Site ID & ppb & $\mathrm{ppb}$ & $\mathrm{ppb}$ & $\mathrm{ppb}$ & ppm & $\mathrm{ppb}$ & $\mathrm{ppb}$ & $\mathrm{ppb}$ & ppm & ppm & ppm & $\mathrm{ppb}$ & $\mathrm{ppb}$ \\
\hline 19/06/2007 11:59 & MS & 170 & 65 & 176 & 9750 & 101 & 159 & 3084 & 11907 & 64 & 12 & 36 & 7166 & 63 \\
\hline 27/06/2007 13:19 & MS & 111 & 48 & 182 & 11521 & 102 & 67 & 2866 & 12085 & 64 & 12 & 36 & 6450 & 76 \\
\hline 02/07/2007 9:11 & MS & 190 & 41 & 175 & 8774 & 93 & 189 & 2876 & 11132 & 62 & 10 & 30 & 6564 & 58 \\
\hline 04/07/2007 9:54 & MS & 284 & 142 & 176 & 6457 & 75 & 358 & 2609 & 8324 & 53 & 7 & 21 & 7655 & 44 \\
\hline 06/07/2007 10:46 & MS & 448 & 141 & 127 & 4254 & 49 & 460 & 2907 & 5411 & 38 & 4 & 12 & 5823 & 30 \\
\hline 06/07/2007 12:23 & MS & 464 & 59 & 112 & 3625 & 42 & 472 & 3311 & 4165 & 32 & 4 & 12 & 4996 & 25 \\
\hline 07/07/2007 9:30 & MS & 547 & 85 & 131 & 3819 & 51 & 459 & 2841 & 4859 & 38 & 4 & 12 & 5915 & 29 \\
\hline 09/07/2007 9:41 & MS & 541 & 36 & 137 & 3970 & 54 & 436 & 2707 & 5279 & 40 & 4 & 12 & 6232 & 30 \\
\hline $11 / 07 / 2007$ 12:36 & MS & 327 & 32 & 142 & 4443 & 59 & 248 & 2855 & 5735 & 42 & 5 & 15 & 6128 & 33 \\
\hline 13/07/2007 10:50 & MS & 305 & 44 & 145 & 4707 & 60 & 243 & 2819 & 5839 & 43 & 5 & 15 & 5956 & 35 \\
\hline 17/07/2007 9:06 & MS & 544 & 52 & 123 & 4123 & 49 & 511 & 2532 & 5100 & 33 & 4 & 12 & 5687 & 35 \\
\hline 23/07/2007 15:42 & MS & 299 & 39 & 144 & 4947 & 64 & 232 & 2344 & 6586 & 43 & 4 & 12 & 5293 & 40 \\
\hline 03/07/2007 14:16 & $\mathrm{SB} A / \mathrm{B}$ & 534 & 250 & 105 & 12875 & 37 & 331 & 8276 & 11715 & 34 & 8 & 24 & 9143 & 102 \\
\hline 04/07/2007 16:21 & SB A/B & 407 & 206 & 118 & 8317 & 37 & 320 & 8292 & 7426 & 25 & 7 & 21 & 8592 & 73 \\
\hline 06/07/2007 15:55 & SB A/B & 1004 & 180 & 95 & 3638 & 24 & 546 & 7058 & 3060 & 16 & 3 & 9 & 5118 & 32 \\
\hline 07/07/2007 10:10 & $\mathrm{SB} A / \mathrm{B}$ & 832 & 112 & 83 & 2988 & 22 & 457 & 6835 & 2590 & 14 & 3 & 9 & 4235 & 26 \\
\hline 09/07/2007 13:03 & SB A/B & 989 & 51 & 90 & 3243 & 24 & 508 & 7554 & 2699 & 16 & 3 & 9 & 4558 & 28 \\
\hline $11 / 07 / 2007$ 15:58 & $\mathrm{SB} A / \mathrm{B}$ & 1140 & 51 & 109 & 3813 & 27 & 676 & 7887 & 3286 & 18 & 3 & 9 & 5151 & 33 \\
\hline 13/07/2007 13:30 & SB A/B & 776 & 110 & 125 & 4979 & 39 & 437 & 9294 & 4687 & 22 & 3 & 9 & 5317 & 44 \\
\hline 15/07/2007 13:46 & SB A/B & 727 & 93 & 117 & 5673 & 43 & 284 & 8351 & 5890 & 24 & 4 & 12 & 4970 & 52 \\
\hline $23 / 07 / 2007$ 15:48 & $\mathrm{SB} A / \mathrm{B}$ & 1014 & 101 & 108 & 4195 & 31 & 679 & 7381 & 3917 & 18 & 3 & 9 & 5325 & 44 \\
\hline 27/06/2007 14:25 & SB B/C & 33 & 57 & 71 & 5791 & 76 & 10 & 4261 & 11656 & 60 & 17 & 51 & 3019 & 67 \\
\hline 02/07/2007 9:54 & $\mathrm{SB} B / C$ & 56 & 70 & 80 & 6380 & 72 & 10 & 4821 & 12495 & 58 & 15 & 45 & 3220 & 74 \\
\hline 04/07/2007 11:01 & $\mathrm{SB} B / C$ & 223 & 91 & 81 & 7036 & 40 & 184 & 7445 & 10174 & 38 & 12 & 36 & 6072 & 68 \\
\hline 06/07/2007 11:29 & $\mathrm{SB} B / \mathrm{C}$ & 724 & 89 & 82 & 3356 & 28 & 402 & 6083 & 5323 & 29 & 9 & 27 & 4442 & 36 \\
\hline 07/07/2007 10:19 & $\mathrm{SB} B / C$ & 678 & 85 & 76 & 2661 & 25 & 336 & 5048 & 4239 & 25 & 8 & 24 & 4038 & 28 \\
\hline 09/07/2007 10:25 & $\mathrm{SB} B / \mathrm{C}$ & 680 & 44 & 81 & 2393 & 28 & 292 & 5787 & 3588 & 22 & 8 & 24 & 4306 & 30 \\
\hline $11 / 07 / 2007$ 13:44 & $\mathrm{SB} B / \mathrm{C}$ & 531 & 57 & 82 & 3656 & 44 & 323 & 6594 & 5788 & 28 & 6 & 18 & 4292 & 40 \\
\hline 13/07/2007 13:29 & $\mathrm{SB} B / C$ & 295 & 95 & 86 & 5460 & 67 & 243 & 6919 & 9219 & 34 & 6 & 18 & 4466 & 66 \\
\hline 15/07/2007 10:43 & $\mathrm{SB} B / \mathrm{C}$ & 227 & 72 & 80 & 5886 & 61 & 173 & 6419 & 9816 & 35 & 6 & 18 & 4111 & 62 \\
\hline 23/07/2007 15:45 & $\mathrm{SB} B / C$ & 475 & 71 & 92 & 4284 & 50 & 280 & 5958 & 7384 & 29 & 6 & 18 & 4617 & 54 \\
\hline 27/06/2007 14:25 & $\mathrm{SB} \mathrm{O} / \mathrm{F}$ & 124 & 116 & 143 & 3380 & 35 & 71 & 1712 & 2761 & 18 & 1 & 3 & 3250 & 31 \\
\hline 02/07/2007 10:01 & $\mathrm{SB} \mathrm{O} / \mathrm{F}$ & 220 & 26 & 142 & 3537 & 35 & 194 & 1846 & 2725 & 17 & 1 & 3 & 4250 & 33 \\
\hline 04/07/2007 11:13 & $\mathrm{SB} \mathrm{O} / \mathrm{F}$ & 276 & 110 & 106 & 3122 & 25 & 380 & 2539 & 2916 & 15 & 1 & 3 & 4731 & 27 \\
\hline 06/07/2007 11:35 & $\mathrm{SB} \mathrm{O} / \mathrm{F}$ & 309 & 30 & 72 & 2353 & 20 & 259 & 4181 & 1901 & 13 & 1 & 3 & 2663 & 18 \\
\hline 07/07/2007 10:28 & $\mathrm{SB} \mathrm{O} / \mathrm{F}$ & 237 & 67 & 87 & 3370 & 24 & 228 & 3028 & 2705 & 17 & 2 & 6 & 3173 & 26 \\
\hline
\end{tabular}

have higher concentrations in the stream than in most of the through flow samples (Fig. 5a, b, Table 1). Clayey soil through flow waters are relatively high in chloride compared to most of the sandy through flow. Sodium and silica concentrations, however, are higher in most of the sandy through flow than in both the clayey through flow and stream water. For silica, higher concentrations in the sandy through flow in the first half of the event are striking (Fig. 5c). These values in the sandy shallow system through flow are in contrast to much lower values in the sandy deep through flow (site MC2, $\mathrm{BC}$ horizon contact).

The relationship between chloride and sodium in through flow and stream flow demonstrates differing water-soil interactions between the sandy and clayey systems (Fig. 6a). In addition, the low-flow stream sample (prior to the event) has the highest chloride of any of the water samples (soil and stream); these stream concentrations of conservative chlo- ride indicate that there is a missing component of the system. There are no known salt deposits in this area of the Mt Lofty Ranges. In order to balance high salinity pre-event stream water, a higher salinity water mass is needed but has not been captured by the sampling in this study. Thus, mass balance attempts with the current data base, using elements such as, silica, calcium, magnesium and potassium, which have many soil water samples with concentrations in excess of the stream values, have resulted in significant negative masses. These mass balance plots and calculations (Milgate, 2007) are not presented here.

A few general observations can be made regarding the elemental concentrations. Stream flow chloride and sodium concentrations have trends during the event similar to clayey soil through flow and overland flow as would be expected for dilution during peak flow (Figs. 5a and 6a). Most sandy shallow soil system through flow samples have lower 
Table 1. Continued.

\begin{tabular}{|c|c|c|c|c|c|c|c|c|c|c|c|c|c|c|}
\hline & & $\mathrm{Al}$ & $\mathrm{Ba}$ & $\mathrm{Br}$ & $\mathrm{Ca}$ & $\mathrm{Cl}$ & $\mathrm{Fe}$ & $\mathrm{K}$ & $\mathrm{Mg}$ & $\mathrm{Na}$ & $\mathrm{S}$ & SO4 & $\mathrm{Si}$ & $\mathrm{Sr}$ \\
\hline Date/Time & Site ID & $\mathrm{ppb}$ & $\mathrm{ppb}$ & $\mathrm{ppb}$ & $\mathrm{ppb}$ & ppm & $\mathrm{ppb}$ & $\mathrm{ppb}$ & $\mathrm{ppb}$ & ppm & ppm & ppm & $\mathrm{ppb}$ & $\mathrm{ppb}$ \\
\hline 09/07/2007 10:29 & $\mathrm{SB} \mathrm{O} / \mathrm{F}$ & 231 & 27 & 90 & 3421 & 25 & 205 & 2989 & 2659 & 17 & 2 & 6 & 3067 & 25 \\
\hline 23/07/2007 16:18 & $\mathrm{SB} \mathrm{O} / \mathrm{F}$ & 435 & 56 & 109 & 4186 & 29 & 434 & 3073 & 3260 & 18 & 2 & 6 & 3379 & 35 \\
\hline 02/07/2007 9:41 & $\mathrm{MC} 1 \mathrm{~A} / \mathrm{B}$ & 5707 & 249 & 71 & 7427 & 17 & 1858 & 2229 & 4164 & 53 & 3 & 9 & 45964 & 15 \\
\hline 03/07/2007 9:41 & $\mathrm{MC} 1 \mathrm{~A} / \mathrm{B}$ & 1498 & 78 & 78 & 5992 & 16 & 747 & 2131 & 3020 & 47 & 3 & 9 & 40039 & 13 \\
\hline 06/07/2007 11:26 & $\mathrm{MC} 1 \mathrm{~A} / \mathrm{B}$ & 3287 & 101 & 55 & 3631 & 13 & 1407 & 1921 & 2616 & 26 & 2 & 6 & 22071 & 8 \\
\hline 08/07/2007 11:26 & MC1 A/B & 2461 & 100 & 44 & 2241 & 18 & 995 & 1952 & 2199 & 21 & 2 & 6 & 11891 & 6 \\
\hline 09/07/2007 10:41 & $\mathrm{MC} 1 \mathrm{~A} / \mathrm{B}$ & 1654 & 100 & 34 & 1596 & 20 & 770 & 2161 & 2028 & 20 & 2 & 6 & 6919 & 6 \\
\hline 10/07/2007 9:30 & $\mathrm{MC} 1 \mathrm{~A} / \mathrm{B}$ & 1749 & 258 & 37 & 1625 & 21 & 902 & 2210 & 2066 & 19 & 3 & 9 & 5168 & 11 \\
\hline 12/07/2007 14:19 & MC1 A/B & 287 & 73 & 132 & 2602 & 72 & 125 & 7508 & 7479 & 34 & 4 & 12 & 4591 & 51 \\
\hline 15/07/2007 13:50 & $\mathrm{MC} 1 \mathrm{~A} / \mathrm{B}$ & 375 & 135 & 168 & 2915 & 75 & 165 & 5487 & 9684 & 42 & 5 & 15 & 4429 & 58 \\
\hline 27/06/2007 11:59 & $\mathrm{MC} 1 \mathrm{~B} / \mathrm{C}$ & 2117 & 102 & 83 & 3613 & 44 & 826 & 2381 & 4679 & 46 & 10 & 30 & 8493 & 27 \\
\hline 02/07/2007 9:51 & $\mathrm{MC} 1 \mathrm{~B} / \mathrm{C}$ & 2285 & 61 & 85 & 2913 & 47 & 876 & 2212 & 4427 & 44 & 10 & 30 & 8923 & 26 \\
\hline 04/07/2007 10:24 & $\mathrm{MC} 1 \mathrm{~B} / \mathrm{C}$ & 390 & 162 & 90 & 3036 & 50 & 217 & 2361 & 4086 & 47 & 13 & 39 & 7236 & 27 \\
\hline 06/07/2007 11:36 & $\mathrm{MC} 1 \mathrm{~B} / \mathrm{C}$ & 3348 & 140 & 80 & 2465 & 38 & 1483 & 2675 & 3746 & 40 & 10 & 30 & 8981 & 26 \\
\hline 08/07/2007 11:36 & $\mathrm{MC} 1 \mathrm{~B} / \mathrm{C}$ & 3562 & 96 & 80 & 2028 & 36 & 1652 & 2647 & 3587 & 37 & 10 & 30 & 8889 & 26 \\
\hline 10/07/2007 10:30 & $\mathrm{MC} 1 \mathrm{~B} / \mathrm{C}$ & 3735 & 137 & 79 & 1731 & 33 & 1574 & 2558 & 3305 & 35 & 10 & 30 & 8873 & 24 \\
\hline 15/07/2007 13:58 & $\mathrm{MC} 1 \mathrm{~B} / \mathrm{C}$ & 7977 & 142 & 77 & 2172 & 29 & 1503 & 2062 & 3826 & 34 & 12 & 36 & 8319 & 25 \\
\hline 27/06/2007 11:59 & $\mathrm{MC} 2 \mathrm{~B} / \mathrm{C}$ & 4556 & 153 & 198 & 17703 & 36 & 3028 & 3845 & 13622 & 107 & 5 & 15 & 45303 & 60 \\
\hline 02/07/2007 9:59 & $\mathrm{MC} 2 \mathrm{~B} / \mathrm{C}$ & 6217 & 103 & 202 & 18872 & 33 & 3402 & 4202 & 14010 & 105 & 4 & 12 & 50517 & 60 \\
\hline 04/07/2007 10:34 & $\mathrm{MC} 2 \mathrm{~B} / \mathrm{C}$ & 483 & 217 & 176 & 8677 & 23 & 835 & 2092 & 5616 & 51 & 7 & 21 & 24437 & 28 \\
\hline 05/07/2007 10:34 & $\mathrm{MC} 2 \mathrm{~B} / \mathrm{C}$ & 3763 & 159 & 191 & 7893 & 21 & 1881 & 2258 & 5536 & 45 & 6 & 18 & 29471 & 26 \\
\hline 06/07/2007 11:46 & $\mathrm{MC} 2 \mathrm{~B} / \mathrm{C}$ & 2790 & 126 & 164 & 6241 & 15 & 1335 & 2230 & 3971 & 41 & 5 & 15 & 22240 & 20 \\
\hline 08/07/2007 11:46 & $\mathrm{MC} 2 \mathrm{~B} / \mathrm{C}$ & 2073 & 108 & 153 & 3967 & 11 & 1122 & 1863 & 2831 & 30 & 5 & 15 & 11781 & 15 \\
\hline 03/07/2007 9:51 & $\mathrm{MC} 2 \mathrm{O} / \mathrm{F}$ & 27 & 112 & 7 & 487 & 4 & 31 & 223 & 371 & 2 & 0.5 & 1.5 & 311 & 6 \\
\hline 05/07/2007 10:34 & $\mathrm{MC} 2 \mathrm{O} / \mathrm{F}$ & 18 & 189 & 16 & 766 & 8 & 12 & 133 & 508 & 5 & 0.5 & 1.5 & 206 & 8 \\
\hline 06/07/2007 11:04 & $\mathrm{MC} 2 \mathrm{O} / \mathrm{F}$ & 10 & 67 & 8 & 220 & 3 & 12 & 127 & 265 & 3 & 0.5 & 1.5 & 90 & 2 \\
\hline 07/07/2007 9:45 & $\mathrm{MC} 2 \mathrm{O} / \mathrm{F}$ & 61 & 114 & 23 & 612 & 8 & 38 & 227 & 640 & 6 & 2 & 6 & 353 & 6 \\
\hline 17/07/2007 9:27 & $\mathrm{MC} 2 \mathrm{O} / \mathrm{F}$ & 27 & 38 & $<5$ & 223 & 2 & 16 & 63 & 134 & 2 & 0.5 & 1.5 & 131 & 1 \\
\hline 10/07/2007 17:07 & MC2 DW & 329 & 173 & 196 & 2869 & 64 & 123 & 2938 & 7647 & 50 & 3 & 9 & 4133 & 42 \\
\hline 11/07/2007 16:05 & MC2 DW & 475 & 158 & 238 & 2719 & 79 & 153 & 3698 & 6809 & 46 & 4 & 12 & 5246 & 53 \\
\hline 13/07/2007 13:34 & MC2 DW & 342 & 107 & 222 & 2530 & 68 & 100 & 3142 & 6836 & 46 & 3 & 9 & 4690 & 45 \\
\hline 17/07/2007 10:26 & MC1 DW & 432 & 272 & 238 & 3274 & 78 & 193 & 2640 & 8826 & 57 & 6 & 18 & 5430 & 49 \\
\hline 29/06/2007 14:25 & $\mathrm{P}$ & 53 & 6 & 15 & 1815 & 6 & 44 & 282 & 491 & 2 & $<1$ & 1.5 & 125 & 9 \\
\hline 05/07/2007 12:34 & $\mathrm{P}$ & 17 & 2 & 16 & 522 & 6 & 14 & 483 & 440 & 3 & $<1$ & 1.5 & 41 & 4 \\
\hline 07/07/2007 11:28 & $\mathrm{P}$ & 7 & 2 & 53 & 473 & 17 & $<10$ & 440 & 1317 & 10 & 2 & 6 & $<40$ & 7 \\
\hline 17/07/2007 12:26 & $\mathrm{P}$ & 27 & 5 & 11 & 281 & 4 & $<10$ & 132 & 366 & 2 & 1 & 3 & 62 & 2 \\
\hline
\end{tabular}

chloride and higher sodium than clayey system through flow (Fig. 6a). Likewise, silica is much higher in these sandy shallow through flow samples (Fig. 6b). The sandy deep through flow show much the same behaviour as clayey system through flow samples (Figs. 5 and 6), although it does not have the potassium concentration of the clayey system (Fig. 6b).

\subsection{Dissolved organic carbon, aluminium and iron}

Dissolved organic carbon analyses were obtained from 34 samples of stream water and selected through flow and overland flow samples (Table 2, Fig. 7a). The lowest concentrations are from sandy soil overland flow $(1.7,2.8 \mathrm{mg} / \mathrm{L})$ and the highest concentration is from clayey soil A horizon from phase I of the event $(31.2 \mathrm{mg} / \mathrm{L})$. In Mackreath Creek, the concentrations of DOC, aluminium, and iron all rise and fall during the event hydrograph (Fig. 7a). The DOC concentration peak occurs between two and three days prior to the peak in iron and aluminium. The concentration increase of these two elements in the stream water during the event is substantial; it is three to four times the pre-event concentrations. DOC has a similar pattern for the event, albeit with the aforementioned earlier peak, and doubles in concentration between low, pre-event flow and early phase II flow. High concentrations of iron and aluminium occur in many of the sandy through flow samples (Fig. 7b). Clayey soil through flow, on the other hand, has concentrations of iron and aluminium below or close to those of the stream waters. These high concentrations of iron and aluminium in soil water do not correspond to high soil water DOC concentrations (Table 2), neither do they correspond to potassium concentrations (Fig. 7c). 
Table 2. Dissolved organic carbon analyses.

\begin{tabular}{|c|c|}
\hline Site ID; Date \& Time & $\mathrm{DOC} \mathrm{mg} / \mathrm{L}$ \\
\hline \multicolumn{2}{|l|}{ MS (stream) } \\
\hline 02/07/2007 9:11 & 13.4 \\
\hline 03/07/2007 9:30 & 17.6 \\
\hline 04/07/2007 9:54 & 22.3 \\
\hline 05/07/2007 9:27 & 25.6 \\
\hline 06/07/2007 10:46 & 25.7 \\
\hline $06 / 07 / 2007$ 12:23 & 25 \\
\hline 08/07/2007 8:19 & 21.8 \\
\hline $11 / 07 / 2007$ 12:36 & 15.5 \\
\hline 13/07/2007 10:50 & 15.2 \\
\hline 15/07/2007 9:39 & 14.8 \\
\hline 17/07/2007 9:06 & 24 \\
\hline \multicolumn{2}{|l|}{ SB OF } \\
\hline 04/07/2007 11:13 & 20.6 \\
\hline 06/07/2007 15:55 & 18.1 \\
\hline 09/07/2007 13:03 & 19.4 \\
\hline \multicolumn{2}{|l|}{ SB AB } \\
\hline 04/07/2007 16:21 & 31.2 \\
\hline 06/07/2007 15:55 & 24.1 \\
\hline 09/07/2007 13:03 & 22 \\
\hline $11 / 07 / 2007$ 15:58 & 23.6 \\
\hline 15/07/2007 13:46 & 14.2 \\
\hline \multicolumn{2}{|l|}{ SB BC } \\
\hline 04/07/2007 11:01 & 22.6 \\
\hline 06/07/2007 15:55 & 16.7 \\
\hline 09/07/2007 13:03 & 13.2 \\
\hline $11 / 07 / 2007$ 15:58 & 13.1 \\
\hline 15/07/2007 13:46 & 11.9 \\
\hline \multicolumn{2}{|l|}{$\mathrm{MC} 1 \mathrm{AB}$} \\
\hline 6/07/2007 9:30 & 23.1 \\
\hline 11/07/2007 16:00 & 9.8 \\
\hline $13 / 07 / 2007$ 13:28 & 10.2 \\
\hline $15 / 07 / 200713: 50$ & 11.9 \\
\hline \multicolumn{2}{|l|}{$\mathrm{MC} 1 \mathrm{BC}$} \\
\hline 15/07/2007 10:00 & 19.2 \\
\hline \multicolumn{2}{|l|}{ MC2 OF } \\
\hline 04/07/2007 10:31 & 4.5 \\
\hline $5 / 07 / 2007$ 10:30 & 2.8 \\
\hline 06/07/2007 11:04 & 1.7 \\
\hline \multicolumn{2}{|l|}{ MC2 DW } \\
\hline $11 / 07 / 2007$ 16:05 & 11.9 \\
\hline $13 / 07 / 2007$ 13:34 & 11.3 \\
\hline
\end{tabular}

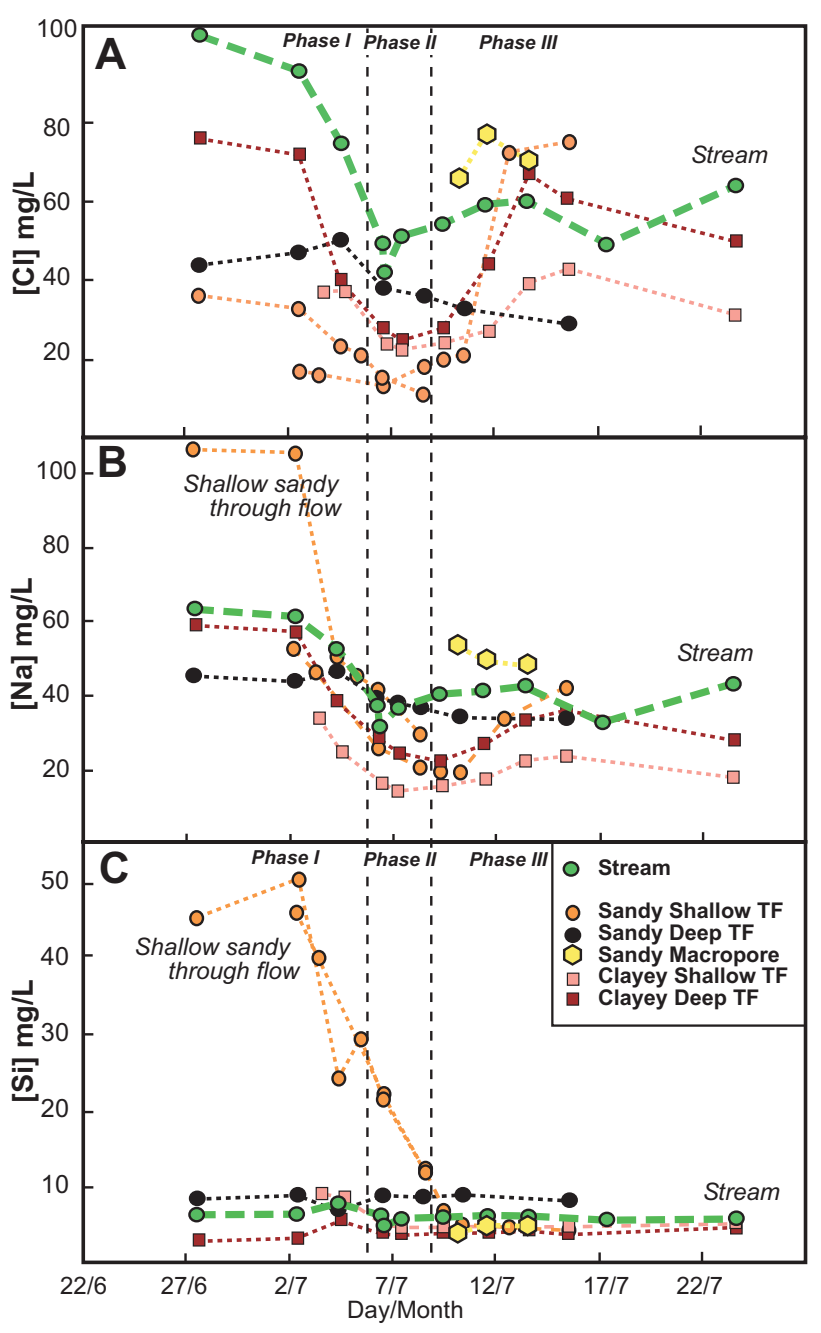

Fig. 5. Time series elemental concentration of (A) chloride, (B) sodium, and (C) silicon in stream waters and soil water through flow (TF) during the measured event. Note high concentrations of sodium and silicon during phase I. Also note generally higher concentrations of chloride and sodium in stream water than in soil water.

\subsection{Oxygen and hydrogen isotopes}

Isotopes of oxygen $\left({ }^{18 / 16} \mathrm{O}\right)$ and hydrogen $\left({ }^{2 / 1} \mathrm{H}\right)$ were sampled over the late June-early July event from Mackreath Creek, soil horizon through flow, overland flow, and precipitation (Figs. 8 and 9). In addition, bulked rainfall samples for April, May, and June were analysed. An important parameter to consider for the analysis of isotopes of oxygen and hydrogen in small catchments is the antecedent moisture condition and the isotopic composition of the pre-event water in the system. In the case of this small, relatively steep ephemeral catchment in a strongly Mediterranean climate, the autumn precipitation leading up to water flowing in the system is particularly important. The characterisation of pre-event water 

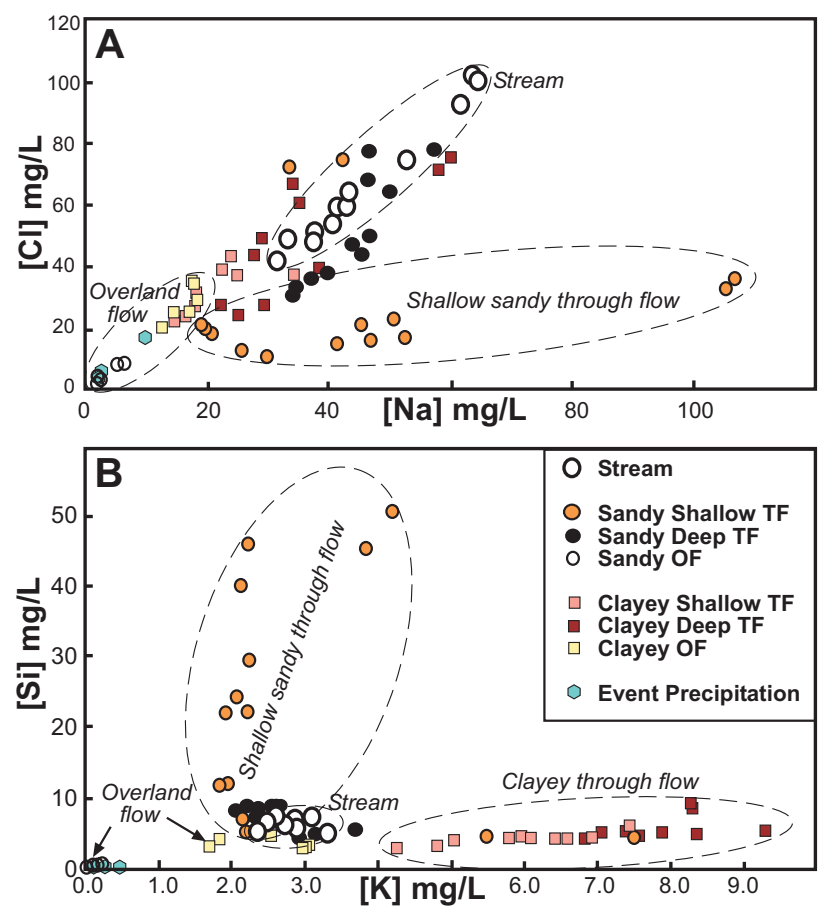

Fig. 6. Scatter plots of (A) sodium and chloride and (B) silicon and potassium in stream waters, soil water through flow (TF) and overland flow (OF) during the measured event. The sandy shallow through flow is high in silicon and sodium compared to other components of the system.

in such a system lacking baseflow is difficult. Vadose zone water prior to the event will be a mix of infiltrated rainfall that has been subjected to different degrees of evaporation. In the case studied here, the previous long dry summer and previous drought year caused a massive soil moisture deficit that is difficult to quantify. In April 2007, following this long dry summer and previous winter drought, a large precipitation event of between 130-150mm occurred over four days. Importantly, this large precipitation event had significantly lower oxygen $\left(\delta^{18} \mathrm{O}\right.$ of $-7.43 \%$ ) and hydrogen $(\delta \mathrm{D}$ of $-45.5 \%$ ) isotopes when compared to more typical winter precipitation events. May 2007 bulk rainfall is more typical of winter rainfall at this elevation in the MLR-Adelaide Hills with $\delta^{18} \mathrm{O}$ of $-5.16 \%$ and $\delta \mathrm{D}$ of $-28.2 \%$ (Kaylaap, 1999). Low water isotope values during heavy precipitation events result from decreased fractionation between vapour and condensate as condensate fraction increases (Kendall \& Doctor, 2007). June 2007 bulk rainfall however has higher isotopic values compared to more typical winter values with $\delta^{18} \mathrm{O}$ of $-2.43 \%$ and $\delta \mathrm{D}$ of $-5.2 \%$. These contrasting isotope values in the lead up to the precipitation event sampled have produced a natural tracer test. Precipitation event water was sampled at three intervals. The first two samples represent the bulk of the event and have an average isotopic composition of $\delta^{18} \mathrm{O}$ of $-3.36 \%$ and $\delta \mathrm{D}$ of $-10.65 \%$. Important to

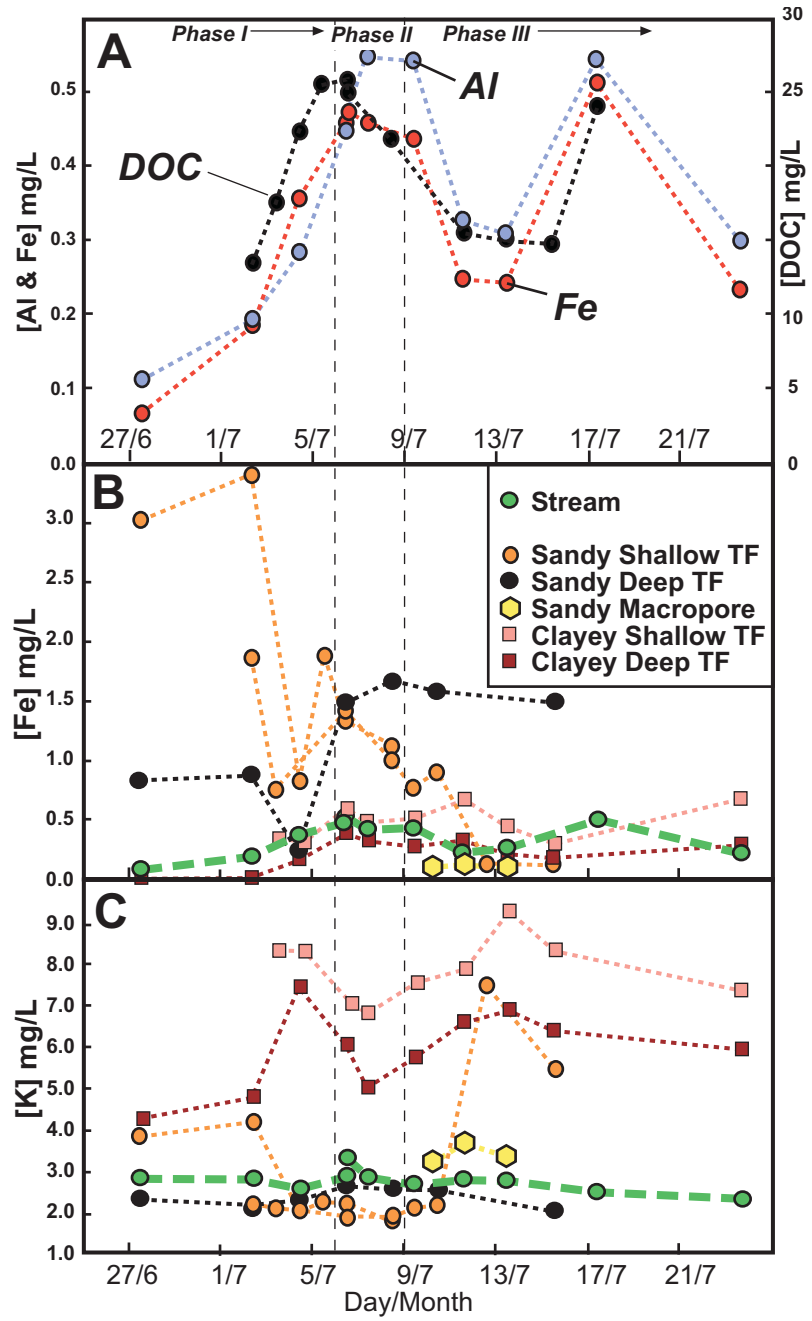

Fig. 7. Time series elemental concentrations of iron, aluminum, potassium, and dissolved organic matter in Mackreath Stream (A), and in soil water through flow (TF) (B and $\mathbf{C})$.

note for the time series of oxygen isotopes (Fig. 8) and hydrogen isotopes (not shown) is that the third sample is considerably lower compared to the first two $\left(\delta^{18} \mathrm{O}\right.$ of -4.98 and $\delta \mathrm{D}$ of $-24.6 \%$ ) and is from a few late small showers.

Important to note from the plot of the time series of oxygen and hydrogen isotopes (Fig. 8, hydrogen isotopes not shown) is that all values are higher than the stream flow except for the sandy deep through flow samples (MC1-BC). This through flow sample site is situated lower on the hill slope and with the collector installed below a clayey sandysilt B horizon. There is a natural seasonal seep a few meters from this site that became active during the wet season. This sandy deep through flow becomes lower in isotopic value during the transition between phase I and II of the event, similar to the stream (Fig. 8b). Shallow soil horizon collectors (from A/B horizon contact) from both the clayey and sandy landscapes show an increase in isotopic values corresponding 


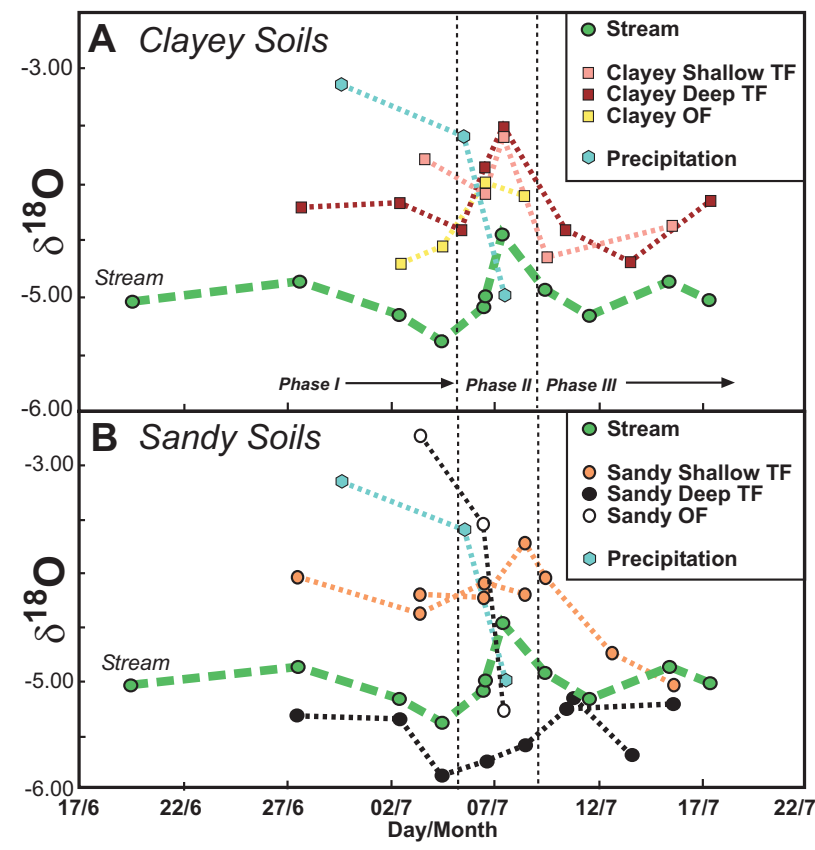

Fig. 8. Times series of oxygen isotopes from clayey soils (A) and sandy soils (B) compared to stream water ( $\mathrm{TF}$ - through flow; OF - overland flow). Sandy deep through flow has lower $\delta^{18} \mathrm{O}$ and $\delta \mathrm{D}$ values. The first two precipitation samples record the vast majority of the event; last sample was of late showers.

to the influx of higher isotopic values of the event water during phase I. However, during phase III, shallow soil water collectors from both sandy and clayey sites show a decrease in isotopic values that is well below the first two event precipitation sample values. Clearly pre-event water that is lower in isotopic value compared to event water mixed into the through flow. Deep through flow collectors in both the clayey and sandy systems show dilution and an increase in isotopic values by event water during phase I followed by a decrease in isotopic values during phase III, again indicating mixing of pre-event water in the through flow system. This decrease in isotopic values in the through flow during phase III is most likely not due to the small volume of water from the late showers which have relatively low isotopic values.

The sandy deep through flow waters are noteworthy for the following reasons: 1) isotopic values are lower than the stream, 2) a depletion trend occurs from phase I to II, similar to the stream, 3) isotopic values do not show any significant increase in isotopic value during the event, indicating minimal mixing of event water with pre-event water.

The isotopic values of the various components of this system (sandy deep through flow, sandy shallow through flow, clayey through flow, event precipitation, and monthly bulked rainfall) are well illustrated by graphing $\delta^{18} \mathrm{O}$ and $\delta \mathrm{D}$ of both the averages of the different components of the system and individual data points (Fig. 9). The bulked rainfall samples of April, May, and June 2007 have a large range of values as has

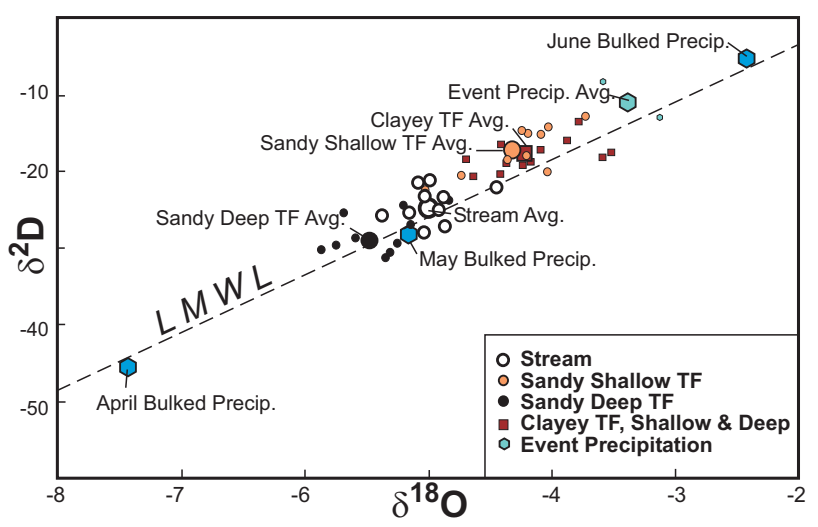

Fig. 9. Averaged isotopic composition ( $\delta \mathrm{D}$ versus $\left.\delta^{18} \mathrm{O}\right)$ of bulked monthly precipitation (April, May, and June, 2007), clayey soil through flow (TF) from both A and B horizons horizon (12 samples), shallow sandy through flow (9 samples), and deep sand through flow (7 samples). Volume averaged event precipitation is also shown. Local meteoric water line (LMWL) from Kayaalp (1999).

been described above. The low isotopic value of the sandy deep through flow and Mackreath Creek are obvious when compared to the event precipitation and other soil through flow samples and averages.

\section{Discussion}

Despite the best efforts of our event sampling, it is clear that the sampling program at Mackreath Creek was incomplete in terms of capturing all significant soil-regolith flow paths. There are important findings from the present study that are directing on-going research. Down-slope change in soil water due to increased residence time within the soil was largely undocumented in the present study but which is presently being investigated. Emergent flow paths in lower slope settings as demonstrated by seasonal seeps present in the area were analysed at a reconnaissance level with field based measurements. It is clear from the range of elemental concentrations that large variations in soil water hydrochemistry are present and that some of these variations are not explained by event water dilution. Nonetheless, a number of interpretations can be made from the data collected.

The overland flow from the clayey soil system reaches parity in its EC and in other elements (Milgate, 2007) with the shallow soil through flow (Fig. 4). This compositional merging soon after peak dilution represents saturation excess overland flow and mixing of a diluted A horizon with overland flow waters. In other words, upslope from the collection point, water was flowing into and out of the A horizon mixing to form a hydrochemically homogenous water mass. Soon after peak rainfall, the compositions diverge with A horizon concentrations increasing and overland flow remaining the same. 
Table 3. Stable isotopes of oxygen and hydrogen.

\begin{tabular}{|c|c|c|c|}
\hline Site ID & Date/Time & Delta O SMOW & Delta D SMOW \\
\hline MS & 19/06/2007 11:59 & -5.04 & -28.1 \\
\hline MS & 27/06/2007 13:19 & -4.87 & -27.3 \\
\hline MS & 02/07/2007 9:11 & -5.16 & -28.4 \\
\hline MS & 04/07/2007 9:54 & -5.38 & -25.7 \\
\hline MS & 06/07/2007 10:46 & -5.08 & -21.5 \\
\hline MS & 06/07/2007 12:23 & -4.99 & -21.3 \\
\hline MS & 07/07/2007 9:30 & -4.45 & -22.2 \\
\hline MS & 09/07/2007 9:41 & -4.93 & -25.1 \\
\hline MS & $11 / 07 / 2007$ 12:36 & -5.15 & -25.4 \\
\hline MS & 15/07/2007 9:39 & -4.86 & -23.7 \\
\hline MS & 17/07/2007 9:06 & -5.02 & -22.8 \\
\hline $\mathrm{SB} A / \mathrm{B}$ & 03/07/2007 14:16 & -3.79 & -13.6 \\
\hline $\mathrm{SB} \mathrm{A} / \mathrm{B}$ & 06/07/2007 15:55 & -4.09 & -17.5 \\
\hline $\mathrm{SB} \mathrm{A} / \mathrm{B}$ & 07/07/2007 10:10 & -3.59 & -18.2 \\
\hline $\mathrm{SB} A / \mathrm{B}$ & 09/07/2007 13:03 & -4.64 & -20.6 \\
\hline $\mathrm{SB} A / \mathrm{B}$ & $15 / 07 / 2007$ 13:46 & -4.37 & -19.0 \\
\hline $\mathrm{SB} B / \mathrm{C}$ & $27 / 06 / 2007$ 14:25 & -4.23 & -18.9 \\
\hline $\mathrm{SB} B / C$ & 02/07/2007 9:54 & -4.18 & -18.6 \\
\hline $\mathrm{SB} B / C$ & 05/07/2007 10:15 & -4.41 & -16.4 \\
\hline $\mathrm{SB} B / \mathrm{C}$ & 06/07/2007 11:29 & -3.87 & -16.1 \\
\hline $\mathrm{SB} B / \mathrm{C}$ & 07/07/2007 10:19 & -3.52 & -17.5 \\
\hline $\mathrm{SB} B / \mathrm{C}$ & 10/07/2007 10:02 & -4.42 & -20.3 \\
\hline $\mathrm{SB} B / C$ & 13/07/2007 13:29 & -4.70 & -18.5 \\
\hline $\mathrm{SB} B / \mathrm{C}$ & 17/07/2007 9:52 & -4.16 & -19.4 \\
\hline $\mathrm{SB} \mathrm{O} / \mathrm{F}$ & 02/07/2007 10:01 & -4.71 & -22.0 \\
\hline $\mathrm{SB} \mathrm{O} / \mathrm{F}$ & 04/07/2007 11:13 & -4.55 & -17.1 \\
\hline $\mathrm{SB} \mathrm{O} / \mathrm{F}$ & 06/07/2007 11:35 & -4.03 & -16.5 \\
\hline $\mathrm{SB} \mathrm{O} / \mathrm{F}$ & 08/07/2007 9:20 & -4.12 & -18.3 \\
\hline
\end{tabular}

The clayey soil system has clear dilution trends between event water and pre-event soil water. The pre-event soil water in the clayey soil horizons is closer to equilibrium with the soil exchange pool as demonstrated by higher concentrations of most elements in the clayey B horizon compared to A horizon and overland flow. Potassium is the notable exception in which the A horizon concentrations are higher than the clayey B horizon. Trends in potassium concentrations in these samples corresponds to DOC concentrations in terms of increases and decreases over time (Milgate, 2007) and most likely reflects release and transport of potassium as organic matter decomposes into DOC. High transient potassium concentration is a typical pattern in forest soils in which rapid release of potassium from decomposing litter commonly exceeds the capacity of the soil to retain it (Laskowski et al., 1995; Chang et al., 2007). Potassium may also be contained in colloidal sized plant material as was reported by Eyrolle et al. (1996).

The concentration peaks of DOC, iron and aluminium in the stream water during the event, as described above, are not in sync by two to three days. Thus, it appears that iron and aluminium are de-coupled from dissolved organic matter, contrary to long-standing work showing these elements are closely linked to DOC and organic colloids (Perdue et al., 1976; Johnson et al., 1981; Tipping, 1981). Organic complex transport of iron and aluminium is especially noted in
Table 3. Continued.

\begin{tabular}{llll}
\hline Site ID & Date/Time & Delta O SMOW & Delta D SMOW \\
\hline MC1 A/B & $03 / 07 / 20079: 41$ & -4.20 & -18.0 \\
MC1 A/B & $06 / 07 / 200711: 26$ & -4.22 & -14.8 \\
MC1 A/B & $08 / 07 / 200711: 26$ & -3.72 & -12.8 \\
MC1 A/B & $09 / 07 / 200710: 41$ & -4.03 & -14.2 \\
MC1 A/B & $12 / 07 / 200714: 19$ & -4.74 & -20.7 \\
MC1 A/B & $15 / 07 / 200713: 50$ & -5.03 & -22.7 \\
MC1 B/C & $27 / 06 / 200711: 59$ & -5.32 & -30.5 \\
MC1 B/C & $02 / 07 / 20079: 41$ & -5.35 & -31.2 \\
MC1 B/C & $04 / 07 / 200710: 24$ & -5.87 & -30.1 \\
MC1 B/C & $06 / 07 / 200711: 36$ & -5.75 & -29.7 \\
MC1 B/C & $08 / 07 / 200711: 36$ & -5.60 & -28.7 \\
MC1 B/C & $10 / 07 / 200710: 30$ & -5.26 & -29.3 \\
MC1 B/C & $15 / 07 / 200713: 58$ & -5.21 & -24.4 \\
MC2 B/C & $27 / 06 / 200711: 59$ & -4.04 & -20.1 \\
MC2 B/C & $03 / 07 / 20079: 51$ & -4.36 & -18.6 \\
MC2 B/C & $06 / 07 / 200711: 46$ & -4.09 & -15.2 \\
MC2 B/C & $08 / 07 / 200711: 46$ & -4.19 & -15.0 \\
MC2 O/F & $03 / 07 / 20079: 51$ & -2.72 & -6.4 \\
MC2 O/F & $06 / 07 / 200711: 04$ & -3.54 & -15.7 \\
MC2 O/F & $07 / 07 / 20079: 45$ & -5.27 & -24.0 \\
MC2 DW & $10 / 07 / 200717: 07$ & -5.14 & -27.1 \\
MC2 DW & $13 / 07 / 200713: 34$ & -5.69 & -25.4 \\
MC1 DW & $17 / 07 / 200710: 26$ & -4.85 & -23.7 \\
P & $29 / 06 / 200714: 25$ & -3.13 & -13.0 \\
P & $05 / 07 / 200712: 34$ & -3.59 & -8.3 \\
P & $07 / 07 / 200711: 28$ & -4.98 & -24.6 \\
\hline
\end{tabular}

tropical settings (Gu et al., 1995; Depré et al., 1999). Instead, due to a combination of the shift in the timing of the concentrations peaks of DOC, iron and aluminium and the lack of correlation between DOC and elevated iron and aluminium concentrations in the through flow waters, colloidal iron oxyhydroxides and clay minerals flushed from some soil horizons may be a more likely explanation. Another possible source of colloids could be remobilised sediment from creek beds; however, in 2007 the previous flow of similar volume occurred two years prior, thus remobilisation is unlikely.

Water samples in this study were filtered to $0.45 \mu \mathrm{m}$, leaving a colloidal fraction, as defined by Buffle and Van Leeuwan (1992) and Stumm (1993), in the $0.20 \mu \mathrm{m}$ to $0.45 \mu \mathrm{m}$ size range. It is clear that the sandy shallow through flow sites showed very elevated levels of iron and aluminium during phase I when compared to stream and clayey soil system (Fig. 7, Table 1). Thus, the elevated iron and aluminium concentrations appear to be associated with flushing of iron oxyhydroxide colloids and clay mineral colloids from sandy shallow soil horizons. Iron colloids have been reported from cool climate systems (Pokrovski and Schott, 2002; Ranville et al., 2005). Ranville et al. (2005) reported from their study of nearby sandy loam soils in the Adelaide Hills that finegrained colloids $(0.1-0.2 \mu \mathrm{m})$ from through flow samples were high in iron whereas, coarser-grained colloids $(0.2-$ $0.5 \mu \mathrm{m})$ contained more aluminium. Additionally, their A2 
horizon samples were deficient in fine-grained colloids, presumably due to translocation of these colloids through the soil profile.

The sandy shallow soil system through flow has elevated concentrations of silica and sodium, compared to the stream and clayey soil system. Mineral weathering (silicate hydrolysis) and release of silica and sodium and to a lesser extent calcium from quartz and feldspar is most likely the dominant factor controlling the high concentrations of these elements in the sandy soil through flow. This mineral weathering is most likely the cause of the distinct hydrochemical trends evident for the sandy shallow through flow when compared to the stream water and clayey soil water (Fig. 6). The highest concentrations of silica, sodium, and calcium come from flushing of sandy A and B horizons during phase I of the event (Fig. 5). Weathering of silicate material, both from in situ soil and from dust, in the presence of soil acids and higher moister contents of the A horizon is probably the cause of these elevated concentrations.

Another factor that could explain the differing elemental concentrations in the various through flow samples is the residence time of soil water in the soil-regolith system. Longer residence time is indicated for the sandy deep through flow system by the dominance of pre-event water in this flow path as deduced from oxygen and hydrogen isotopes. The lowest $\delta^{18} \mathrm{O}$ and $\delta \mathrm{D}$ water, and therefore the water that is the most strongly influence by pre-event water (sandy deep through flow; MC1-BC) has consistent hydrochemical trends for the seven isotopic and most elemental samples analysed. The narrow range of values for MC1-BC is intermediate between the high silica and sodium sandy shallow through flow waters and the clayey through flow waters in terms of most elemental concentrations (Fig. 6). Thus, although MC1-BC demonstrates the best case for longer residence time based on the presence of pre-event water, this flow path does not show elevated concentrations of silica, sodium, and calcium that would be expected from prolonged water-mineral interactions. However, MC1-BC does show very substantial increases in iron and aluminium during the second half of the event (Fig. 7), which is interpreted as a result of mixing of early (flushed) event water with pre-event water.

A through flow pulse of macropore water was identified in the sandy soil system based on field observations of trenches filling with water and active macropore flow. Samples of this through flow pulse have elevated chloride, sodium, magnesium, and potassium concentrations but relatively lower silica, iron and aluminium concentrations (Figs. 5 and 7, Mg and $\mathrm{Al}$ not shown). Thus, a possible scenario is that this pulse flushed dissolved solids from deep in the soil-regolith profile. Why this water was not elevated in silica, from silicate mineral hydrolysis, is not known. One possibility is that the pre-event water from the April event may have infiltrated the soil without extensive flushing of exchangeable constituents due to the very dry nature of the landscape prior to this precipitation event.
A possible model to explain hydrochemical data is as follows. Infiltration in the sandy soil system prior to the measured event accumulates in the regolith above the bedrockregolith boundary. This pre-event water has low values of ${ }^{18} \mathrm{O}$ and ${ }^{2} \mathrm{H}$ isotopes obtained from the large April event and to a lesser degree from May precipitation. When compared to later through flow from the sandy soil system, this pre-event water is not exceedingly high in dissolved constituents. High concentrations of silica, iron, and aluminium, and other mineral-oxide related elements appear to originate from event flushing of sandy soil A and B horizons during phase I.

The clayey soil system by contrast has lower concentrations of ${ }^{18} \mathrm{O}$ and ${ }^{2} \mathrm{H}$ isotopes, especially early in the event (phase I). This demonstrates the higher saturation and shorter residence time of water in the clayey soil A and B horizons. That the B horizon has a lowering of isotopic values as the event progresses, indicating that water, probably from deeper in the regolith and dominated by pre-event water (from April and May), was pushed out and subsequently mixed with higher isotopic ratio surface event water.

Further support of this model of quick flow through the upper clayey soil system and delayed flow through the sandy soil system can be interpreted from DOC, iron, and aluminium concentration peaks observed in the stream during the course of the event. The DOC concentration peak occurs two to three days prior to iron and aluminium concentrations peaks, as has been described. The DOC peak most likely originates from clayey soil system A horizons which have both high DOC concentrations and rapid storm response. The iron and aluminium peaks are probably due to transported colloids (iron hydroxides and clay minerals) from flushing of sandy soil horizons. Pre event water in the sandy soil system from early rains in April and May do not show elevated concentrations of iron and aluminium. These waters infiltrated through the same sandy soil system as event waters that were much higher in iron and aluminium. Two possibilities are: 1) colloids from earlier flushing settled and or were filtered in the deep regolith prior to re-mobilization during the measured event. 2) Initial rain water that infiltrated the sandy soil system did not contain substantial amounts of flushed colloids; the reason for this is not known but could be due to the severe dryness of the landscape prior to this initial April event. Nonetheless, the measured event shows high concentrations of iron and aluminium coming from sandy soil horizons early in the event. These colloids were probably transported through the porous sandy medium and into the stream. The clayey soil system, on the other hand, has much lower concentrations of iron and aluminium, probably due to filtering by matrix soil flow and by flow through disconnected macropores. Macropores would act as avenues of colloidal flushing, however, colloids could accumulate on macropore surfaces and be deposited in macropores plugging these flow paths. 


\section{Conclusions}

The small ephemeral Mackreath Creek catchment has a complicated hydraulic and hydrochemical response to winter precipitation events. Following a long dry summer and a preceding drought year (2006), this hilly catchment did not generate stream flows until over $200 \mathrm{~mm}$ of precipitation fell during late autumn rains. This autumn drought breaking precipitation in April 2007 acted as a natural tracer test due to its low $\delta^{18} \mathrm{O}$ and $\delta \mathrm{D}$ isotopic composition when compared to average winter rains and later rains in May and June. Most of this April precipitation flowed through the clayey soil system and was replaced by water from the May and June events by the time the late June-early July event occurred. By contrast, the sandy soil system apparently stored a significant portion of this water which was then displaced by event water. This displacement caused the stream water during the event to be dominated by this pre-event water, although the clayey soil system was largely dominated by event water.

Soil water flow pathways (and overland flow) before, during and after the event have distinctive hydrochemical characteristics. The clayey soil system is predictable in that it exhibits dilution by event water and increase in concentrations of most elements from overland flow to the A horizons and to the B horizon. Potassium is the exception which is highest in the A horizon, most likely due to higher amounts of organic matter and its decomposition and release of potassium. Overland flow from the sandy soil system has the lowest elemental concentrations; this is due to high infiltration rates and lack of saturation excess overland flow.

Deep through flow in the sandy system was identified mainly on the basis of oxygen and hydrogen isotopes. Strongly contrasting oxygen and hydrogen isotopes of autumn and early winter precipitation combined with a severe soil moisture deficit prior to detailed measurement created a natural tracer experiment.

Acknowledgements. This project was funded by Flinders University Program Grant (2006-2009), and South Australia Water Corporation grant. Access to field sites was provided by SA Water and Department of Parks and Wildlife, SA.

Edited by: J. Seibert

\section{References}

Aberg, G., Jacks, G., and Hamilton, P. J.: Weathering rates and 87Sr/86Sr ratios: an isotopic approach, J. Hydrol., 109, 65-78, 1989.

Barnett, S. R., van den Akker, J., and Zulfic, D.: Mount Lofty Ranges Groundwater Assessment, Upper Onkaparinga Catchment, S. Aust. Dept. Water, Land and Biodiversity Conservation, Report, DWLBC 2002/29, 2002.

Brown, V. A., McDonnell, J. J., Burns, D. A., and Kendall, C.: The role of event water, a rapid shallow flow component, and catchment size in a summer stormflow, J. Hydrol., 217, 171-190, 1999.

Buffle, J. and Van Leeuwen, H. P.: Environmental particles: 1. In Environmental Analytical and Physical Chemistry Series, Lewis Publishers, London, p. 554, 1992.

Bureau of Meteorology: Climate Statistics for Australian sites, online available: www.bom.gov.au, 2007.

Buttle, J. M.: Fundamentals of small catchment hydrology, In: Isotope Tracers in Catchment Hydrology, edited by: Kendall. C. and McDonnell, J. J., Elsevier, Amsterdam, 1-49, 1998.

Chang, S.-C., Wang, C.-P., Feng, C-M., Rainer Rees, R., Hell, U., and Matzner, E.: Soil fluxes of mineral elements and dissolved organic matter following manipulation of leaf litter input in a Taiwan Chamaecyparis forest, Forest Ecol. Manag., 242, 133141, 2007.

Chittleborough, D. J., Smettem, K. R. J., Costaris, E., and Leaney, F. W.: Seasonal Changes in Pathways of Dissolved Organic Carbon through a Hillslope Soil (Xeralf) with Contrasting Texture, Australian J. Soil Res., 30, 465-476, 1992.

Cox, J. W., Chittleborough, D. J., Brown, H. J., Pitman, A., and Varcoe, J. C. R.: Seasonal changes in hydrochemistry along a toposequence of texture-contrast soils, Australian J. Soil Res., 40, 581-604, 2002.

Dupré, B., Viers, J., Dandurand, J. L., Polvé, M., Bénézeth, P., Vervier, P., and Braun, J. J.: Major and trace elements associated with colloids in organic-rich river waters: ultrafiltration of natural and spiked solutions, Chem. Geol., 160, 63-80, 1999.

Edmond, J. M., Palmer, M. R., Measures, C. I., Grant, B., and Stallard, R. F.: The fluvial geochemistry and denudation rate of the Guayana Shield in Venezuela, Colombia and Brazil, Geochim.Cosmochim. Acta, 59, 3301-3325, 1995.

Eyrolle, F., Benedetti, M. F., Benaim, J.-Y., and Fevrier, D.: The distributions of colloidal and dissolved organic carbon, major elements and trace elements in small tropical catchments, Geochim. Cosmochim. Acta, 60, 3643-3656, 1996.

Genereux, D. P. and Hooper, R. P.: Oxygen and hydrogen isotopes in rainfall-runoff studies, in: Isotope Tracers in Catchment Hydrology, edited by: Kendall, C. and McDonnell, J. J., Elsevier, Amsterdam, 319-346, 1998.

Gu, B., Schmitt, J., Chen, Z., Liang, L., and McCarthy, J. F.: Adsorption and desorption of different organic matter fractions on iron oxide, Geochim. Cosmochim. Acta, 59, 219-229, 1995.

Harrington, G.: Hydrogeological Investigation of the Mount Lofty Ranges, Progress Report 3: Borehole water and formation characteristics at the Scott Bottom research site, Scott Creek Catchment, Department of Water, Land and Biodiversity Conservation, Report DWLBC Adelaide Australia, 2004/03, 2004a.

Harrington, G.: Hydrogeological Investigation of the Mount Lofty Ranges, Progress Report 4: Groundwater - surface water interactions in the Scott Creek, Marne River and Tookayerta Creek Catchments, Department of Water, Land and Biodiversity Conservation, Report DWLBC, Adelaide Australia, 2004/11, 2004b.

James-Smith, J. M. and Harrington, G. A.: Hydrogeological Investigation of the Mount Lofty Ranges, Progress Report 1: hydrogeology and drilling phase 1 for Scott Creek Catchment, Department of Water, Land and Biodiversity Conservation, Report DWLBC Adelaide Australia, 2002/17, 2002.

Johnson, N. M., Driscoll, C. T., Eaton, J. S., Likens, G. E., and McDowell, W. H.: "Acid rain", dissolved aluminum and chemi- 
cal weathering at the Hubbard Brook Experimental Forest, New Hampshire, Geochim. Cosmoshim. Acta, 45, 1421-1437, 1981.

Kayaalp, A. S.: Application of rainfall chemistry and isotope data in hydrometeorological modelling, $\mathrm{PhD}$ Thesis, Flinders University of South Australia, 1999.

Kendall, C. and Doctor, D. H.: Stable isotope applications in hydrologic studies; in Treatise on Geochemistry, Elsevier, Netherlands, 319-364, 2007.

Kennedy, V. C., Kendall, C., Zellweger, G. W., Wyerman, T. A., and Avanzino, R. J.: Determination of the components of stormflow using water chemistry and environmental isotopes, Mattole river basin, California, J. Hydrol., 84, 107-140, 1986.

Kump, L. R., Brantley, S. L., and Arthur, M. A.: Chemical weathering, atmospheric $\mathrm{CO}_{2}$ and climate, Annual Reviews Earth Planetary Science, 28, 611-667, 2000.

Land, M., Ingri, J., Andersson, P. S., and Ohlander, B.: Ba/Sr, $\mathrm{Ca} / \mathrm{Sr}$ and ${ }^{87} \mathrm{Sr} /{ }^{86} \mathrm{Sr}$ ratios in soil water and groundwater: implications for relative contributions to stream water discharge, Appl. Geochem., 15, 311-325, 2000.

Laskowski, R., Berg, B., Johansson, M. B., and McClaugherty, C.: Release pattern for potassium from decomposing forest needle and leaf litter, Long term decomposition in a Scots pine forest, Canadian J. Botany, 73, 2019-2027, 1995.

Leaney, F. W., Smettem, K. R. J., and Chittleborough, D. J.: Estimating the contribution of preferential flow to subsurface runoff from a hillslope using deuterium and chloride, J. Hydrol., 143, 83-103, 1993.

Likens, G. E., Bormann, F. H., Pierce, R. S., Eaton, J. S., and Johnson, N. M.: Biogeochemistry of a Forested Ecosystem, Springer, New York, 1977.

Likens, G. E., Driscoll, C. T., and Buso, D. C.: Long-term effects of acid rain: response and recovery of a forested ecosystem, Science, 272, 244-246, 1996.

Lin, H.: Hydropedology: Bridging Disciplines, scales and data, Vadose Zone J., 2, 1-11, 2003.

McDonnell, J. J., Stewart, M. K., and Owens, I. F.: Efferts of catchment-scale subsurface watershed on stream isotopic response, Water Resour. Res., 26, 3065-3073, 1991.

McGlynn, B. L., McDonnel, J. J., and Brammer, D. D.: A review of the evolving perceptual model of hillslope flowpaths at the Maimai catchments, New Zealand, J. Hydrol., 257, 1-26, 2002.

Milgate, S. A.: Hydrochemical investigation of flow pathways through quartz-sand and duplex soils during a storm event: Mackreath Creek, Mount Lofty Ranges, Unpublished honours thesis, Flinders University of South Australia, Adelaide Australia, p. 50, 2007.

Newman, B. D., Campbell, A. R., and Wilcox, B. P.: Lateral subsurface flow pathways in a semiarid ponderosa pine hillslope, Water Resour. Res., 34, 3485-3496, 1998.

Pearce, A. J., Stewart, M. K., and Sklash, M. G.: Storm runoff in humid headwater catchments 1 . Where does the water come from?, Water Resour. Res., 22, 1263-1272, 1986.

Perdue, E. M., Beck, K. C., and Reuter, J. H.: Organic complexes of iron and aluminium in natural waters, Nature, 260, 418-420, 1976.
Pinder, G. F. and Jones, J. F.: Determination of the ground-water component of peak discharge from the chemistry of total runoff, Water Resour. Res., 5, 438-445, 1969.

Pokrovski, O. S. and Schott, J.: Iron colloids/organic matter associated transport of major and trace elements in small boreal rivers and their estuaries (NW Russia), Chem. Geol., 190, 141-181, 2002.

Preiss, W. V.: The Adelaide Geosyncline: Late proterozoic stratigraphy, sedimentation, palaeontology and tectonics, Bull. Geol. Surv. S. Australia, 53, p. 439, 1987.

Probst, A., Dambrine, E., Viville, D., and Fritz, B.: Influence of acid atmospheric inputs on surface water chemistry and mineral fluxes in a declining spruce stand within a small granitic catchment (Vosges massif, France), J. Hydrol., 116, 101-124, 1990.

Ranville, J. F., Chittleborough, D. J., and Beckett, R.: Particle-Size and Element Distributions of Soil Colloids: Implications for Colloid Transport, Soil Science Soc. Amer. J., 69, 1173-1184, 2005.

Shand, P., Darbyshire, D. P. F., Gooddy, D., and Haria, A. H.: $87 \mathrm{Sr} / 86 \mathrm{Sr}$ as an indicator of flowpaths and weathering rates in the Plynlimon experimental catchments, Wales, UK, Chem. Geol., 236, 247-265, 2007.

Shanley, J. B., Kendall, C., Smith, T. E., Wolock, D. M., and McDonnell, J. J.: Controls on old and new water contributions to stream flow at some nested catchments in Vermont, USA, Hydrol. Processes, 16, 589-609, 2002.

Sklash, M. G. and Farvolden, R. N.: The role of ground water in storm runoff, J. Hydrol., 43, 45-65, 1979.

Sklash, M. G. and Farvolden, R. N.: The use of environmental isotopes in the study of high-runoff episodes in streams, in: Isotope Studies of Hydrologic Processes, edited by: Perry Jr., E. C. and Montgomery, C. W., Northern Illinois University Press, DeKalb, Illinois, 65-73, 1982.

Sklash, M. G., Farvolden, R. N., and Fritz, P.: A conceptual model of watershed response to rainfall, developed through the use of oxygen-18 as a natural tracer, Can. J. Earth Sci., 13, 271-283, 1976.

Smettem, K. R. J., Chittleborough, J. J., Richards, B. G., and Leaney, F. W.: The influence of macropores on runoff generation from a hillslope with a contrasting textural class, J. Hydrol., 122, 235-252, 1991.

Stevens, D. P., Cox, J. W., and Chittleborough, D. J.: Pathways of phosphorous, nitrogen, and carbon movement over and through texturally differentiated soils, South Australia, Australian J. Soil Res., 37, 679-693, 1999.

Stumm, W.: Aquatic colloids as chemical reactants: surface structure and reactivity, Coll. Surf., A73, 1-18, 1993.

Taylor, J. K., Thomson, B. P., and Shepherd, R. G.: The soils and geology of the Adelaide Area, Bulletin 46 Geol. Survey S. Aust., p. $85,1974$.

Tipping, E.: The adsorption of humic substances by iron oxides, Geochim. Cosmochim. Acta, 45, 191-199, 1981. 